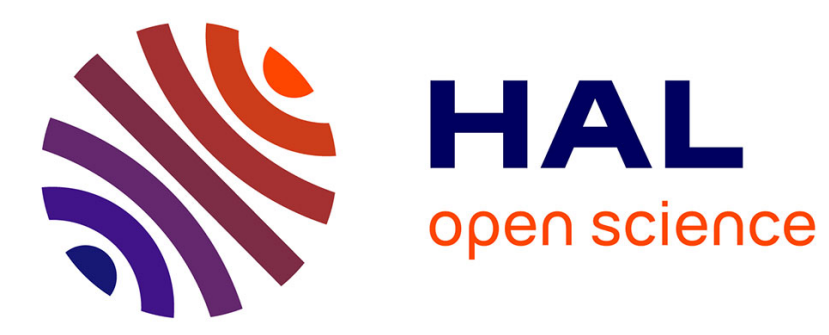

\title{
The Repair Society
}

E. Gerasimova, Sofia Tchouikina

\section{- To cite this version:}

E. Gerasimova, Sofia Tchouikina. The Repair Society. Russian Studies in History, 2009, 48 (1), pp.58-74. 10.2753/RSH1061-1983480104 . halshs-01904582

\section{HAL Id: halshs-01904582 \\ https://shs.hal.science/halshs-01904582}

Submitted on 26 Oct 2018

HAL is a multi-disciplinary open access archive for the deposit and dissemination of scientific research documents, whether they are published or not. The documents may come from teaching and research institutions in France or abroad, or from public or private research centers.
L'archive ouverte pluridisciplinaire HAL, est destinée au dépôt et à la diffusion de documents scientifiques de niveau recherche, publiés ou non, émanant des établissements d'enseignement et de recherche français ou étrangers, des laboratoires publics ou privés. 


\section{Ekaterina Gerasimova ANd Sofia Tchoukina}

\section{The Repair Society}

This astonishing experimentation-it is here called remonteaffects not only Moscow; it is Russian.

—Walter Benjamin (Moscow, 1927)

Consumer services are in such a deplorable state that literally every Russian must know how to do plumbing repairs, wallpaper a room, assemble a bookshelf, replace electrical wiring, whitewash a ceiling, paint a floor, and so on. Russia is to all intents and purposes a vast do-it-yourself workshop.

-A foreigner on post-Soviet Russia ${ }^{1}$

Although the practices of repair are to some extent characteristic of any society, the economic and social contexts, the cultural 
meanings, and the integration of repairs into specific sets of practices can significantly differ. The considerations of frugality that determined the repair of old things in poor neighborhoods and the restoration of antiques to decorate a sumptuous villa are equally focused on prolonging the life of objects. But the repaired items themselves (necessities versus luxuries) and the motivations for their refurbishment (pragmatic versus symbolic), the social groups (poor versus rich) involved, and the methods of repair (performed in a domestic setting or by cheap labor with minimum specialization versus performed by professional and specialized labor) differ. Both examples nevertheless demonstrate a connection between the practices and cultural views of what constitutes repair and what constitutes restoration, the role the object plays in the person's life and in the integration/differentiation of social groups, which item can be considered trash and in what context and which an antique, and so forth. The socio-anthropological literature over the last ten to twenty years has invested things with the right to a life of their own in society and to the function of mediation in social relations. ${ }^{2}$ It has even declared things to be equally entitled social agents. ${ }^{3}$ This approach to analysis of the material environment, supplemented with ethnographic and historical observations, seems to us a productive way of understanding the specifics of everyday life in Soviet society.

Soviet society may be called a repair society. ${ }^{4}$ The planned economy was not self-regulating (as a market economy is) and was therefore the object of constant improvement, experiment, and mandatory anticrisis campaigns implemented by the authorities, meaning that it was perpetually under repair. The citizens were also actively involved in the system's "repair projects," in terms both of officially sanctioned social activism (consumer movements, the fight against substandard products, letters of complaint to the newspapers) and of the everyday economy, in which case they adapted the system for their own comfort (by pulling strings, visiting flea markets, using homemade goods, pilfering products from factories, applying the informal reallocation of goods, etc.).

A repair society shares many characteristics with preindustrial societies, where things were also kept in use for a long time and 
possessed great value, which facilitated the establishment of intimate relationships between owner and item and the attribution of numerous symbolic meanings, including the sacred, to an object. In a traditional society, the material environment changed little over the life of one generation; things had permanence and could long outlive their makers and first owners. Objects connected generations and ensured stability in the material world. Repair was a routine practice that was also transmitted from generation to generation, underpinned by personal knowledge, especially since there was no set place to "discard" an item. It could only be completely destroyed or transformed into something else.

The industrial society changed the attitude toward things. Things become goods and now actively circulate in a system of exchange, moving from one proprietor to the next and changing in monetary value. Industrially produced things forfeit the aura of authenticity and the veneer of holiness..$^{5}$ Many things that were once transferred only by legacy have become generally accessible, and the life of things becomes shorter and of less value, which makes them more attractive to the masses thirsting for material satiety. The postindustrial capitalist society has been defined far more by consumption than by production, while production itself is becoming increasingly symbolic. ${ }^{6}$ The consumer society is opposed to the repair of things (and relationships), preferring the new to anything old. Being economically unable to continue chasing after fashion and technical perfection, individual social groups in mass consumption societies are forced to continue employing the practices of the "culture of poverty," which includes putting things to collective and prolonged use and producing analogues of industrially manufactured things at home. Other social groups that have the wherewithal to acquire massproduced merchandise are instead bent on exclusivity, frequently preferring handmade or obsolete and therefore rare goods, which the vogue for vintage has encouraged. ${ }^{7}$ Others are reviving the practices of repair and reuse of objects, campaigning on behalf of the environment and in favor of reducing the significance of material values. Still others find in domestic handicrafts and the ability to make things a source of self-actualization and a leisure 
activity (hobby). The overwhelming majority of the population in economically developed countries nevertheless prefers acquiring something new over fixing something old. It is more convenient and often less expensive, and it is also a way of responding to psychological and social requirements characteristic of postindustrial societies (shopping therapy, the achievement of an individual style, a striving for technical perfection, and the like). Practices of repair are marginal in those societies and are becoming increasingly marginal in today's Russia, where the cost of fixing something old can exceed the cost of a replacement bought new from China.

Repair is a set of techniques that prolong the life of objects by restoring to them their pragmatic or symbolic function. Broadly speaking, this can include fixing the item, adapting it to a secondary use, using it as material from which to make something else, redefining its symbolic status, changing the context in which it is utilized, and the like. Several factors contributed to the viability of this practice in Soviet society. First, traditional peasant cultural practices (the preservation and lengthy use of items, the transmission of repair skills and the independent production of objects) persisted in Soviet Russia. Second, wars, revolution, and poverty taught people frugality and thrift, instilled into them the skills needed to make things over, facilitated barter, and separated the symbolic from the material aspect of things. Third, the Soviet economy of insufficient and low-quality goods prompted people to keep their repair skills honed. Fourth, state regulation of consumption and propaganda urging a certain standard way of relating to things promoted the practices of repair. Below we examine in greater detail the last two factors and the everyday practices among the populace that served to create a Soviet repair society "from the bottom up."8

\section{The Repair Economy and the Ideology of Repair in the USSR}

Soviet propaganda endorsed an attitude toward things based on a subject/subject concept, rather than the subject/object relationships 
with things formulated by Russian constructivists in the 1920 s. $^{9}$ The Soviet attitude toward an object was supposed to be free of fetishism, alienation, or commercial calculation. Soviet people regarded a thing not as a good [tovar] but as a good comrade [tovarishch], and therefore they prolonged its life and valued in it reliability and genuineness over an attractive appearance. ${ }^{10} \mathrm{~A}$ Soviet-made object was supposed to serve a person long and devotedly, and it could not be discarded even if it began to lose its functional properties (in the same way as you do not forsake an injured friend). From the opposite standpoint, friendship (like any other personal relationship) was not to hinder Soviet citizens from discharging their duty to Party, collective, or motherland and was not to hamper the struggle for a radiant communist future. Therefore, excessive attention to daily life and to things ("philistinism" [meshchanstvo] and "fixation on things" [veshchizm]) was censured, especially during periods when the temptation to succumb to the enticements of a comfortable life surrounded by pleasant things was particularly great (during the New Economic Policy [NEP] and the Thaw).

With every ideological twist and turn, certain everyday items became "anti-Soviet," whereas others came to symbolize conformity with the party line. ${ }^{11}$ Under War Communism, it was deemed "petty bourgeois" to own a comb or a handkerchief. Later, combs, handkerchiefs, soap, and toothbrushes were rehabilitated, but the stock-in-trade of the "NEPman"-knobbed bedsteads, down pillows and silk sofa throws, mirrored cupboards-came in for criticism. During the First Five-Year Plan and the cultural revolution, New Year celebrations and their accoutermentstrees and the toys used to decorate trees-were prohibited, and children's playthings were also censured. ${ }^{12}$ During the Second Five-Year Plan, when the state began to focus on light industry, many Soviet-made items and even food-Sovetskoe "champagne," Red Moscow perfume, Saliut watches, lampshades, rugs, and curtains-appeared as symbols of the well-to-do and "civilized" life being led by shock workers [udarniki]. ${ }^{13}$ During the Thaw, objects that had migrated in from Western countries, bringing with them elements of the Western lifestyle (for example, the outfits worn by "Yanks" [shtatniki] and "zoot-suiters" [stiliagi]), were 
labeled "hazardous." Overall, though, the ideological danger to a dominant, controlling state always came from the individualized objects of private life that symbolized a departure from a collective mode of existence and the manifestation of personal tastes and preferences. Soviet ideologues attributed to things an important socializing function: an "improper" thing could turn a person into a slacker, a profligate, or an individualist, prompting him to adopt a depraved lifestyle and even to betray his motherland. The individual was seen as extraordinarily dependent on things in the environment and as subject to their influence. ${ }^{14}$ For this reason, the weakening of that connection and the exertion of ideological control over the milieu created by things were important tasks for Soviet ideology. The state tried to shape a "Soviet consumer" with "rational desires" by propagandizing standards of good taste. For Soviet people, taste was far from personal, not merely an issue of aesthetic preferences but an important social and political choice. ${ }^{15}$ "Modesty" and "simplicity" were signs of good taste; consumers were pointed toward the mass-based, median consumption that would shield them equally from "vestiges of the past" and the "hot pursuit of fashion."

The small selection of industrially produced merchandise, which was strictly governed by scientifically developed and rarely modified standards (the GOST series of state standards), frequently did not include goods of sought-after dimensions, configurations, or construction, thus forcing consumers to adapt the goods being sold or look for another way to acquire an item that actually matched their requirements. ${ }^{16}$ The basic emphasis on the functional rather than the symbolic characteristics of merchandise (modishness, originality, attractiveness) and the state trading monopoly, which did not depend on sales, made it possible to neglect real consumer tastes for a long time. But in the 1960s and the 1970s, the party leadership, as a component of its attempt to introduce elements of "management by the people" and "democracy from below," began to encourage the development of a consumer movement and the study of consumer demand. That "glasnost" allowed numerous instances of the unreliability of Soviet goods and their nonconformity to the requirements of the 
citizenry to find their way into complaint and suggestion books and the deficiency reports and feuilletons printed in newspapers. ${ }^{17}$ The situation did not, however, substantially improve.

Many Soviet-produced goods had functional or symbolic defects designed into them, but inexpensive yet low-quality semifinished items could be brought into (or returned to) a condition fit for consumption at low cost. The state's effective "repair strategy" was to develop a huge sector to repair things and keep a large number of people employed. A whole network of household service centers and various repair services (which themselves did not, however, perform outstanding work) partially offset the failures of production. The repair shops (for shoes, clothing, domestic appliances, and furniture) in Moscow and Leningrad during the 1960s and the 1970s numbered in the thousands. ${ }^{18}$ Completed footwear repairs and customizations in Leningrad and Leningrad oblast, for example, brought in 9,500,000 rubles in 1970 and 13,800,000 rubles in 1975, while clothing repairs accounted for 30,000,000 rubles in 1970 and 33,400,000 rubles in $1975 .{ }^{19}$

The state also looked favorably on the independent manufacture of economically necessary and ideologically appropriate items. When the lampshade was declared a symbol of domestic comfort during the Second Five-Year Plan, for example, women's magazines began dispensing copious advice on how to make lampshades at home. ${ }^{20}$ This happened again during the vogue for lampshades in the late 1950s: "table lamps with shades made of silk or sturdy textured cloth are very decorative. The housewife can make such a lamp herself." ${ }^{21}$ The books Handy Hints [Poleznye sovety] and The Domestic Encyclopedia [Domashniaia entsiklopediia], the magazines Sdelai sam, Nauka $i$ zhizn', Rabotnitsa, and Krest'ianka, and specialized newspaper features offered information to the handy. Handy Hints (1960) explained that "it is not difficult to make for yourself," out of materials readily to hand, racks for footwear and hats, coat hangers, lampshades, minishelves, a dish rack, a lamp, a mailbox, a chaise longue, a toiletry case, a hold-all, a shower, a mop, a window-cleaning tool, a thermos, and a pan trivet. It also showed how to fix furniture, 
clothing, footwear, various household items, sinks, commodes, electrical devices, and an apartment in general, and how to make glue out of flour and mend ladders in stockings.

The state regulation of consumption and of relationships with the world of things was not specific to the Soviet Union. During and after the war, for example, the British government launched a nationwide campaign of "make do and mend." Not until Great Britain got its industries up and running, as declared by the magnificent Britain Can Make It exhibition of 1946, did the ideology begin to call for the support of domestic industrial production and to approve the consumption of massproduced goods. Making things for oneself and performing repairs transitioned from survival strategies to the hobby of "do it yourself." 22 Soviet ideology was less honest with its citizens: it declared that Soviet industry could indeed "make it," but in practical terms, that more often than not implied a need to adapt and repair.

\section{Repair in the Domestic Economy and Relationships with Things}

For all the state's fear of goods fetishism and its attempts to regulate consumption, consumer demand increased and differentiated, and material well-being became more significant to social self-determination, in the desire to follow rapidly changing fashions and to own a certain range of objects as a guarantee of "normalcy." ${ }^{23}$ Unlike the impoverished, only financially dispossessed inhabitants of the flourishing West, however, even people in the Soviet Union who had money could not buy what they wanted or follow a certain style. At this point, we are more interested in the "aftermarket" phase of the life of objects in the Soviet domestic economy, since once goods are brought into the home, they are cleansed of their commercial associations, are assimilated, and become "personal possessions." 24 But, since the relationships between Soviet people and things were also shaped at the acquisition stage, we must touch briefly on the conditions under which the future owner first encountered things (including in the form of goods). 
The attitude toward things was shaped during the process in which need matured and items were acquired. Goods were "procured" [dostavali]; trips were made to other towns or cities to obtain desired items; they were purchased "under the counter" and from middlemen. In the Soviet Union, people lived on dreams of a future prosperity for which they were preparing in the present by buying various amenities: often carpets were purchased for a future apartment or bed linens for future grandchildren. One of our female informants recalled her husband buying furniture in hopes of being allocated an apartment at some future time and placing it, still in its packaging, in the corner of their room, where it stood for several years. With constant shortages of first one thing and then another, purchases made "in case of emergency" provided a sense of security. Frequently, people tended to categorize everything that required them to stand in line to buy as something that must be in short supply, even if they later did not know where to put what they had bought or how to use it. Goods bought on impulse were either set aside ("for a gift" or until the time was right) or resold. Sometimes people bought patently inappropriate things or rejects that could be made over and used for other than their intended purpose.

Several important conclusions stem from this brief recital of the "idiosyncrasies of Soviet shopping." First, the impossibility of straightforwardly acquiring an object made that object more desirable (by increasing what Georg Simmel called its "subjective value") and molded "proxy" relations between the thing and its future owner. The encounter was eagerly anticipated and, moreover, required from the consumer additional efforts and know-how to make it happen. The "acquisition" of the thing often came with a moral choice. Were strings to be pulled? Was a bribe to be offered? Was a coupon received at work to be passed on to someone else? Was the state to be cheated by pretending that the refrigerator was being purchased for one's father, the veteran? Was an acquired thing to be sold to an acquaintance at the official price? This is why our informants' narratives paid more attention to these "flirtations" with things than their utilization.

Second, the practices of purchase stimulated further informal 
social and economic interactions-swaps, sales, repair, makeovers, gifting, packages sent to relatives, bequests of deficit goods. Things facilitated horizontal and vertical communication and integration in society. They were drawn into the network of social relations, as both mediators and active participants. Third, the inability to buy desired or necessary things narrowed the individualization of consumption and restricted subjective taste. It became necessary to concentrate on an object's function rather than on its symbolic meaning. Consumption continued to fulfill its function of social differentiation, although much less than in capitalist society: the intelligentsia valued books (as goods of a certain type), whereas "philistines" valued carpets and chandeliers. ${ }^{25}$

Fourth, in Soviet life, the conversion of a recently purchased good into a useful household item often required making it over and adapting it to its prescribed functions. We now explore this element in greater detail.

As mentioned above, the low quality of Soviet goods and the absence of choice let to merchandise being perceived as semifinished and invariably in need of some final touches. So, for example, the newspaper Leningradskaia pravda (1963) described an instance where a woman styled " $B$ " bought a beaver-lamb coat (for 144 rubles, 40 kopeks!) and while still in the store "noticed that it was rather too large." But she decided to have it retailored and so took it to a dressmaker's, where it was completely ruined. ${ }^{26}$ That logic was entirely typical: things had to be jumped at when they were "up for grabs," and later one would figure out how the thing could be used. Soviet merchandise was, furthermore, standardized and often crudely made, so before it could be used it had to be tailored to the individual owner. The adaption and mutual habituation between objects and people was often long and painful: breaking in a pair of boots, getting used to the uncomfortable handle of a tool, taking in a dress and repositioning buttons, developing a special way of wearing a shirt to hide the defect under the arm, dying violet tights black, having to wash a sweater several times before the color stopped running and tinting the underwear, carefully tuning a television, adapting furniture to fit in a small apartment, and so on. The goods themselves 
prompted active personalization through their transformation and mutual adaption. ${ }^{27}$ Sometimes after being thus "assimilated," the item acquired a unique character and could be correctly used only by its owner. ${ }^{28}$ An old object was kept for a long time before being thrown away not only because a new one was expensive or unavailable but also because the painful stage of mutual abrasion between the owner and the old object 0 had already run its course.

The interviews teem with accounts of the repair and adaption of things to everyday life and of the adaption of people to things. Those accounts make especially frequent use of verbs with the prefixes pod- and pri- [indicating an addition or a "tweak"Trans.]: poddelat', podshit', podognut', prisposobit', pridelat', privernut', prisobachit', and prolovchit 'sia. Here is one excerpt:

It was in the early 1960s.... We had no hot water; the boiler wasn't working.... The boiler was German, written off by some ship. My brother worked for a steamship line, you see, and they'd pulled it off that ship and thrown it away. It was no use to anyone. It was broken, so my brother bought it for scrap.

We brought it home. We patched it-there was a crack in it-we patched it and set it up and it worked for us for ... for many years it worked for us. In the time I lived there, I adapted [prisposobilsia] to that boiler. I was used to it. In the morning I got up and stoked it. I tipped - we fixed up these special buckets to make it easier-I tipped a bucket of coal in, I tamped it down so that it wouldn't flare up. I'd go to work, come home from work, clean it out again.... At first, of course, I was all over the place until I got used to it, but then I adapted, and how!" (A.V.)

Repairs performed in the Soviet economy almost always involved the improvisation known as bricolage. ${ }^{29}$ Many examples of how people in the Soviet Union adapted old objects have become proverbial: rugs made of old tights and scraps, sweat pants cut up into dusters, seedlings planted in cardboard milk containers, and the like. Some of our informants even kept an eye out for items that could easily be made over. This was especially typical of clothing and footwear after the war, when people went to the flea market looking for things "to alter." Stories of furniture found at a dump and made over are emblematic. In a special case, 
old furniture was indiscriminately discarded in the 1960s when people were moving into new apartments, then picked up by others who used any available means and their own skills to turn those household effects into salable "antiques."

The faith that a thing has infinite functional potential and will always be good for something implied a need to create a pool of bricolage-ready items. Every home had a pigeonhole, a box, a shelf where bits and pieces were stored away. For an object to be discarded, it would have to have irretrievably lost all the qualities of a useful item. Useless things were normally relegated to the periphery (to the dacha) and only after several decades there were some sent to the dump. Frequently a paradoxical situation arose, where people (who usually classed themselves as intellectuals) fiercely criticized the fixation on things while living in apartments full of useless objects that they could not throw out.

I have this old sofa. It's broken and sagging. I prop it up with boxes, because the sofa, which was given to us by close friends ... keep and use everything, I say. To me, it's a tragedy to throw something out, not because I begrudge the money but because it makes me feel small, not being able to use it. So I try to remake everything, so that nothing's wasted. Make everything over, make a napkin, a wrap, a rug out of something, to extend its life as best one can. So as to keep it around, to make something of it ... and perhaps have something to give. But I can't simply toss it. (N.B.)

As we can see, for this woman the prolongation of an object's life involves not simply technical skills or considerations of frugality but also a moral assessment. The bricolage stories gave our subjects a way of telling the interviewer something good and impressive about themselves and their nearest and dearest, those Mr. and Ms. Fix-Its, the masters of all trades and both sexes. Repair and bricolage skills were also of importance in underwriting gender status. The repair of apartments, furniture, dachas, and vehicles was the province of men, who proudly showed their interviewers entresol shelving, regular shelves, and devices that they had made with their own hands and told about the domestic appliances and bicycles they had fixed and how much they loved their work tools. Women applied their domestic talents to whipping up a meal "out 
of nothing" and making ornaments, interior decor, and, first and foremost, clothing.

There was a graduation party at the technical college. Our boss came and said that there was going to be a graduation party on Vasil'evskii Island, in some club there, and they'd invited some sailors to be our partners. So then, I had to make a dress, but what with? I went to Nevskii Avenue, to that store called Flax that was opposite Gostinyi Dvor. I bought a linen bed sheet and made a pleated skirt, a sailor's jacket, a blouse with a sailor collar; and I embroidered anchors on it.... There were some scraps left, and they would work for shoes. I went to buy heels. I made the shoes myself. (O.A.)

Repair and bricolage skills had significance in moral and social evaluations (a "good housewife," a "master of all trades"); practical wisdom and usefulness to the community enhanced people's authority and expanded their social networks. Under late socialism, however, people in the Soviet Union were less eager to stand out from the crowd with the assistance of authentic things made at home (a leading motif in consumption societies) than to be affiliated with the social organism and with groups that were consuming prestigious objects. The interviewees often mentioned their desire to have things "that people have" or "that everyone has," and it was this desire that prompted them to produce ostensibly industrially manufactured things possessing great symbolic value. Sweaters and skirts were knitted from styles seen on the silver screen and given fake "designer" labels; underground dressmakers worked from patterns made by unpicking imported apparel; jeans from India were bleached to give them a "designer" look; Soviet audio equipment received amateur upgrades to approximate "hifi," and so on. The ability to produce a proficient imitation of a status symbol was an important social skill.

The specific character of Soviet society consisted in the fact that permanent repair as a form of creativity and lifestyle was not the lot of the dispossessed but an experience shared by most of the population. It was a zone where the individual was in control and could create his or her own symbolic arrangements, a sphere of activity that was independent of the state. Know-how 
and ingenuity were required not only to make a cozy home but also to fulfill production plans and implement the decisions of a shortsighted management. Given the scarcity of resources and the poor production equipment and organization (amid a constant insistence that the plan must be "fulfilled"), citizens were forced to "muddle through," becoming experts in research and development and successful inventors. The workers we interviewed reported that the only way to keep production running was by "staying on their toes." They spoke with particular reverence of a tool that was itself often custom-made or adapted for a certain job. The category of bricolage may also encompass the litany of excuses for a worker's absence from work, the domestic use of goods pilfered from work, the aspiration to stand in three sales-register lines at once, the rapid reaction to anything in short supply that has been discarded, and much more. Much as Lévi-Strauss employed the term "bricolage" to signify a particular kind of local logic, we may equally well speak of the "bricolagic" structure of the Soviet mind, which contrived to associate ideological constructs that were not altogether logically associative, to utilize propagandized ideas and phrases delivered from various podiums together with practical know-how and an antistate everyday morality, to live publicly and privately with equal sincerity, and to excel in other varieties of mental versatility. ${ }^{30}$

\section{Notes}

1. www.langust.ru/review/xenorusa.shtml. [The first epigraph is from Walter Benjamin, Selected Writings, trans. Rodney Livingstone and others (Cambridge, MA: Belknap, 1999), vol. 2: 1927-1934, p. 29.-Trans. All Web addresses accessed February 2009.-Ed.]

2. See Iu.M. Lotman, Besedy o russkoi kul'ture (St. Petersburg, 2002), pp. 5-16; Arjun Appadurai, ed., The Social Life of Things: Commodities in Cultural Perspective (Cambridge: Cambridge University Press, 1996); Mary Douglas and Baron C. Isherwood, The World of Goods: Towards an Anthropology of Consumption (London: Allen Lane, 1996); Celia Lury, Consumer Culture (Cambridge: Cambridge University Press, 1996).

3. Some examples are Tim Dant, Material Culture in the Social World: Values, Activities, Lifestyles (Philadelphia: Open University Press, 1999); Alfred Gell, Art and Agency: An Anthropological Theory (Oxford: Oxford University Press, 1998), pp. 12-20; Karin Knorr Cetina, "Sociality with Objects: Social 
Relations in Postsocial Knowledge Societies," Theory, Culture, and Society, vol. 14, no. 4 (1997), pp. 1-30; Bruno Latour, "When Things Strike Back: A Possible Contribution of 'Science Studies' to the Social Sciences," British Journal of Sociology, vol. 51, no. 1 (2000), pp. 107-23; and Laurent Thévenot, "Pragmatic Regimes Governing the Engagement with the World," in The Practice Turn in Contemporary Theory, ed. Theodore R. Schatzki, Karin Knorr Cetina, and Eike von Savigny (London: Routledge, 2001), pp. 56-73.

4. The idea of viewing repair as a macrolevel phenomenon relative to the economic system was expressed by Vadim Volkov in a discussion of that topic at a summer practicum course and the idea of superimposing a "repair-focused" schema on interpersonal relations (of family and friendship) in the Soviet Union by Viktor Kaplun. We are grateful to our colleagues for their intellectual assistance. Ekaterina Gerasimova would also like to express her gratitude to her colleagues at the University of Sheffield (Susan Reid, Nicky Gregson, David Shepherd, Katerina Cook, Linda Moss, and others) and the Centre for the Study of Domestic Interior (Royal College of Art, London) for discussing this topic with her. Special thanks go to Tatyana Rose (Philip Price Memorial). $<<$ Cook, Moss, Rose-names ok? >>

5. On the loss of art objects' aura of authenticity in an age of mass production, see V. Ben'iamin, "Proizvedenie iskusstva v epokhu ego tekhnicheskoi vosproizvodimosti," in his Izbrannye proizvedeniia (Moscow, 1996), pp. 15-65 [Walter Benjamin, "The Work of Art in the Age of Mechanical Reproduction," available at www.marxists.org/reference/subject/philosophy/works/ge/benjamin. htm-Trans.]. On the loss of the sacred "thingliness" of things, see M. Khaidegger, Vremia i bytie. Stat' $i$ i vystupleniia [Martin Heidegger, Being and Time] (Moscow, 1993), pp. 316-26.

6. See, for example, Zh. Bodriiar, Sistema veshchei [Jean Baudrillard, The System of Objects] (Moscow, 1993); Baudrillard, La Société de consummation, ses mythes, ses structures (Paris: Gallimard, 1970); and Scott Lash and John Urry, Economies of Signs and Space (London: Sage Publications, 1994).

7. The striving toward authenticity in domestically made products is interpreted as a reaction against modernism and mass production (Judy Attfield, Wild Things: The Material Culture of Everyday Life [Oxford: Berg, 2000], pp. 78-79).

8. The empirical basis is provided by a hundred or so interviews with St. Petersburg residents born between 1910 and 1980. The references to, and detailed accounts of, things and practices of handling them were a "by-product" of the interviews; most of them were not directly elicited by the interviewer.

9. E. Degot', "Ot tovara k tovarishchu. K estetike nerynochnogo predmeta" (www.ruthenia.ru/logos/number/2000_5_6/2000_5-6_04.htm); Christina Kiaer, "Rodchenko in Paris," in The Consumption Reader, ed. David B. Clarke, Marcus

A. Doel, and Kate M.L. Housiaux (London: Routledge, 2003), pp. 193-96.

10. Degot", "Ot tovara k tovarishchu."

11. On consumption in Soviet Russia, see N. Lebina and A. Chistikov, Obyvatel' i reformy. Kartiny povsednevnoi zhizni gorozhan v gody NEPa $i$ khrushchevskogo desiatiletiia (St. Petersburg, 2003); Jukka Gronow, Caviar with Champagne: Common Luxury and the Ideals of the Good Life in Stalin's Russia (Leisure, Consumption, and Culture) (Oxford: Berg, 2003); and Julie Hessler, A 
Social History of Soviet Trade: Trade Policy, Retail Practices, and Consumption, 1917-1953 (Princeton, NJ: Princeton University Press, 2004).

12. Karen Petrone, Life Has Become More Joyous, Comrades: Celebrations in the Time of Stalin (Bloomington: Indiana University Press, 2000); Robert W. Thurston, "The Soviet Family during the Great Terror, 1935-1941," Soviet Studies, vol. 43, no. 3 (1991), pp. 553-74.

13. V. Volkov, "Kontseptsiia kul'turnosti, 1935-1938 gody: sovetskaia tsivilizatsiia i povsednevnost' stalinskogo vremeni," Sotsiologicheskii zhurnal, 1996, nos. 1-2, pp. 194-214; Gronow, Caviar with Champagne.

14. Remember that the first quarrel between Pavka Korchagin [the heroic protagonist of Nikolai Ostrovskii's How the Steel Was Tempered (Kak zakalalas' stal') - Trans.] and his "petty bourgeois" girlfriend was over her unsuitable attire.

15. Just take Lev Kassil'"s priceless A Matter of Taste [Delo vkusa, a didactic book for young people on resisting "vulgarity, philistinism, and tastelessness"Trans.], which was published in 1958.

16. So, the Mosbel'e Trust's underwear catalogue, which presented the fashions for the 1936-37 season, offered nine kinds of night gowns, eight kinds of slips, and only two brassiere styles (O. Gurova, "Istoriia veshchei v sovetskoi Rossii [na primere nizhnego bel'ia]," an unpublished candidate's dissertation).

17. E. Bogdanova, "Gazetnye zhaloby kak strategiia zashchity potrebitel'skikh interesov. Pozdnesovetskii period," Teleskop: nabliudeniia za povsednevnoi zhizn'iu peterburzhtsev, 2002, no. 6, pp. 44-48. Our analysis also relied on newspaper archives and interviews collected by Bogdanova, which she kindly made available to us.

18. Moskva v tsifrakh (1966-1970 gg.). Kratkii statisticheskii sbornik (Moscow, 1970), p. 109; Narodnoe khoziaistvo Leningrada i Leningradskoi oblasti za 60 let. Statisticheskii sbornik (Leningrad, 1977), p. 91.

19. Moskva v tsifrakh (1966-1970 gg.), p. 91.

20. Volkov, "Kontseptsiia kul' turnosti."

21. Poleznye sovety (Leningrad, 1960), p. 9.

22. David Jeremiah, Architecture and Design for the Family in Britain, 1900-1970 (Manchester: Manchester University Press, 2000).

23. Furthermore, researchers believe that this policy facilitated an "emphasis on consumption," since "material plenty was an essential measure of the advancement of the Soviet socialist system" (Caroline Humphrey, The Unmaking of Soviet Life: Everyday Economies After Socialism [Ithaca, NY: Cornell University Press, 2002], p. 53). See also Katherine Verdery, The Transition from Socialism: Anthropology and Eastern Europe (Cambridge: Cambridge University Press, 1992), referenced by Humphrey, The Unmaking of Soviet Life, p. 53; and Milena Veenis, "Consumption in East Germany: The Seduction and Betrayal of Things," Journal of Material Culture, vol. 4, no. 1 (1999), pp. 79-112. The state promoted that emphasis, reinforcing its citizens' officially approved conduct by handing out deficit goods and according preferential status in the acquisition of such items.

24. Attfield, Wild Things, pp. 144-45; Daniel Miller, Material Culture and Mass Consumption (Oxford: Basil Blackwell, 1987); P.K. Lunt and S.M. Livingstone, Mass Consumption and Personal Identity: Everyday Economic Experience (Buckingham: Open University Press, 1992), p. 16; Lury, Consumer Culture. 
25. A classic work on this topic is Pierre Bourdieu's La Distinction: Critique sociale du jugement (Paris: Éditions de Minuit, 1979).

26. "Servis ne terpit ravnodushnykh," Leningradskaia pravda, 29 March 1963, p. 2.

27. Bolstering her argument with examples such as these, Ekaterina Degot' defines the Soviet world, contrary to established stereotypes, as one of highly individualized—not standardized and impersonal—-things.

28. The French sociologist Laurent Thévenot defines this type of interaction with the material world as belonging to the "regime of familiarity," in which the agent possesses autonomy of action (Thévenot, "Pragmatic Regimes Governing the Engagement with the World").

29. From the French word bricoleur, a jack-of-all-trades able to repair and create using any available means.

30. K. Levi-Stross, Pervobytnoe myshlenie (Moscow, 1994). pp. 126-30. [A discussion of bricolage is found on pp. 16-36 of Claude Lévi-Strauss, The Savage Mind (Chicago: University of Chicago Press, 1966); his discussion of local logics begins on p. 161.--Trans.] 